\title{
Outbreak of Fusarium oxysporum f. sp. lycopersici race 3 in commercial fresh-market tomato fields in Rio de Janeiro State, Brazil
}

\author{
Ailton Reis ${ }^{1,2}$; Leonardo S Boiteux ${ }^{1,2}$ \\ ${ }^{1}$ Embrapa Hortaliças, C. Postal 218, 70359-970 Brasília-DF Brazil; ${ }^{2 B}$ Bolsista CNPq; ailton@cnph.embrapa.br
}

\begin{abstract}
Fusarium wilt, caused by three races of Fusarium oxysporum f. sp. lycopersici, is one of the most important tomato diseases. In Brazil, all three races were reported, however, race 3 has been so far restricted only to Espírito Santo State. In the present work, seven F. oxysporum isolates obtained from wilted plants of the race 1 and 2-resistant tomato hybrids ‘Giovana', ‘Carmen’ and 'Alambra’ in São José de Ubá and Itaocara (Rio de Janeiro State, Brazil) were characterized at race level. Virulence assays were performed using a set of race differential cultivars: 'Ponderosa' (susceptible to all races), 'IPA-5' (resistant to race 1), 'Floradade' (resistant to races 1 and 2), 'BHRS2,3' (resistant to all three races). Two wild tomato accessions (Solanum pennellii 'LA 716' e S. chilense 'LA 1967') previously reported as resistant to all Brazilian isolates of $F$. oxysporum $\mathrm{f}$. sp. lycopersici were also evaluated. Isolates from São José de Ubá and Itaocara were highly virulent to 'Ponderosa', 'IPA-5' and 'Floradade'. They were also able to infect a few plants of 'BHRS-2,3', inducing vascular browning and wilt symptoms. Solanum pennellii and $S$. chilense accessions displayed an extreme (immune-like) resistant response. These results indicated that all seven isolates could be classified as F. oxysporum f. sp. lycopersici race 3, expanding the geographical distribution of this pathogen within Brazil. The hypothesis of transmission via contaminated seeds is reinforced after the present report, which confirms the almost simultaneous outbreak of race 3 in two geographically isolated tomato-growing areas in Brazil (Espirito Santo and Rio de Janeiro). Evaluation of commercial seed lots imported into Brazil for contamination with the pathogen would be necessary in order to avoid nation-wide spread of this serious disease.
\end{abstract}

Keywords: Lycopersicon, Fusuarium wilt, pathogen variability.

\section{RESUMO}

Ocorrência da raça 3 de Fusarium oxysporum f. sp. lycopersici em lavouras comerciais de tomate para mesa no estado do Rio de Janeiro

A murcha-de-fusário, causada por três raças do fungo Fusarium oxysporum f. sp. lycopersici, é uma das doenças mais importantes do tomateiro. No Brasil, as três raças já foram relatadas, entretanto a raça três encontrava-se restrita apenas ao estado do Espírito Santo. Neste trabalho, sete isolados de $F$. oxysporum obtidos de plantas com sintomas de murcha, dos híbridos de tomate 'Giovana', 'Carmen’ e ‘Alambra’, em São José de Ubá e Itaocara (estado do Rio de Janeiro) foram caracterizados a nível de raça. Um ensaio de virulência foi conduzido utilizando-se um conjunto de cultivares diferenciadoras de raças: 'Ponderosa' (suscetível a todas as raças), 'IPA-5' (resistente à raça 1), 'Floradade' (resistente às raças 1 e 2) e 'BHRS-2,3' (resistente às três raças). Dois acessos de tomate selvagens (Solanum. pennellii 'LA 716' e S. chilense 'LA 1967'), previamente registrados como resistentes a isolados das três raças de $F$. oxysporum f. sp. lycopersici, também foram avaliados. Os isolados de São José de Ubá e Itaocara foram altamente virulentos sobre ponderosa 'Ponderosa', 'IPA-5' e 'Floradade' conseguiram infectar algumas plantas de 'BHRS-2,3', induzindo descoloração vascular e uma leve murcha. Solanum pennellii e S. chilense mostraram uma resposta de extrema resistência aos isolados avaliados. Estes resultados indicaram que os sete isolados podem ser classificados como F. oxysporum f. sp. lycopersici raça 3, estendendo a distribuição geográfica desta raça do patógeno no Brasil. Este relato reforça a hipótese de transmissão da doença via sementes contaminadas, uma vez que registra o quase simultâneo aparecimento do mesmo patógeno em duas áreas de produção de tomate geograficamente isoladas (Espirito Santo e Rio de Janeiro). A avaliação de lotes de sementes comerciais importadas para contaminação com este patógeno se faz necessária a fim de evitar a disseminação desta doença para outros estados do Brasil.

Palavras-chave: Lycopersicon, Murcha-de-fusário, variabilidade patogênica.

(Recebido para publicação em 25 de agosto de 2006; aceito em 17 de julho de 2007)

F usarium wilt, caused by three races of Fusarium oxysporum Schlechtend.:Fr. f. sp. lycopersici (Sacc.) W.C. Snyder \& H.N. Hans is a major fungal diseases of tomato (Solanum lycopersicum L. = Lycopersicon esculentum Mill.). Fusarium oxysporum f. sp. lycopersici is a soil-borne pathogen, but there is strong indication that it can be introduced into new growing areas via contaminated seeds (Jones, 1991; Jones
\& Woltz, 1981). Races 1 and 2 have a world-wide distribution, whereas race 3 has a more limited geographical range (Reis et al., 2005). Traditionally, the three races are classified by inoculating a standard group of differential accessions carrying Fusarium wilt racespecific resistance genes: I for resistance to race 1 (Bohn \& Tucker, 1940); I-2 for resistance to race 2 (Alexander \& Tucker, 1945; Alexander \& Hoover, 1955; Simons et al., 1998) and I-3 for resistance to race 3 (Grattidge \& O’Brien, 1982; Volin \& Jones, 1982; Scott \& Jones, 1985; Hemming et al., 2004).

In Brazil, the first report of a Fusarium wilt race 1 isolate was done in São Paulo State (Arruda, 1941). All additional surveys conducted in Brazil reported only isolates belonging to race 1 and/or race 2 (Kurozawa \& Pavan, 1998). More recently, a group of isolates able to cause wilt symptoms in race 1 
Table 1. Reaction of race differential accessions to Fusarium oxysporum f. sp. lycopersici isolates, collected in Rio de Janeiro State, Brazil, (Reação de acessos diferenciadores de raça a isolados de Fusarium oxysporum f. sp. lycopersici, coletados no Estado do Rio de Janeiro), Brasilia, Embrapa Hortaliças, 2006.

\begin{tabular}{lccccccc}
\hline \multirow{2}{*}{ Isolate } & \multicolumn{7}{c}{ Reaction to the race differential } \\
\cline { 2 - 7 } & Ponderosa & IPA-5 & Floradade & BHRS-2,3 & CNPH-409 & CNPH-410 & Race \\
\hline CNPH-023** $^{*}$ & 3,9 & 4,2 & 1,0 & 1,0 & 1,0 & 1,0 & 2 \\
CNPH-027 * $^{*}$ & 4,1 & 1,0 & 1,0 & 1,0 & 1,0 & 1,0 & 1 \\
CNPH-089** $^{*}$ & 4,0 & 4,3 & 4,2 & 1,1 & 1,0 & 1,0 & 3 \\
CNPH-150 $^{n}$ & 4,7 & 4,7 & 4,7 & 1,2 & 1,0 & 1,0 & 3 \\
CNPH-151 & 4,3 & 4,7 & 4,5 & 1,4 & 1,0 & 1,0 & 3 \\
CNPH-152 & 4,2 & 4,3 & 4,3 & 1,3 & 1,0 & 1,0 & 3 \\
CNPH-153 & 4,8 & 4,7 & 4,7 & 1,3 & 1,0 & 1,0 & 3 \\
CNPH-154 & 3,9 & 4,1 & 4,7 & 1,3 & 1,0 & 1,0 & 3 \\
CNPH-155 & 4,2 & 4,7 & 4,5 & 1,2 & 1,0 & 1,0 & 3 \\
CNPH-156 & 4,5 & 4,7 & 4,7 & 1,4 & 1,0 & 1,0 & 3 \\
\hline
\end{tabular}

*Average of 12 plants, evaluated by using an ordinal scale ranging from $1=$ no symptoms to 5

= dead plants (média de 12 plantas, avaliadas com uma escala ordinal de notas, variando de 1

= ausência de sintomas a 5 = plantas mortas); ${ }^{* *}$ Used as controls (usados como controle).

and 2 resistant $\mathrm{F}_{1}$ hybrids 'Carmen' and 'Alambra' were identified in Venda Nova dos Imigrantes and Domingos Martins counties (Espírito Santo State, Brazil) (Reis et al., 2005). This was later confirmed to be the first report of $F$. oxysporum f. sp. lycopersici race 3 in the country and the pathogen was thus far restricted only to Espírito Santo State (Reis et al., 2005). However, in the year 2006, plants displaying typical Fusarium wilt symptoms were also found in commercial fields employing a group of race 1 and race 2 resistant fresh-market tomato hybrids in São José de Ubá and Itaocara Counties (Rio de Janeiro State, Brazil). In the present work we report the virulence assays with these isolates and confirm that they represent the first formal report of $F$. oxysporum f. sp. lycopersici race 3 in Rio de Janeiro State, Brazil.

\section{MATERIAL AND METHODS}

\section{Fusarium oxysporum isolates}

Two isolates were obtained from distinct wilted plants of the $\mathrm{F}_{1}$ hybrid 'Carmen', two from 'Alambra' and two from 'Giovana' in three different commercial fields in São José de Ubá county. One additional isolate was obtained from a wilted plant of the $\mathrm{F}_{1}$ hybrid ‘Carmen' in Itaocara county, Rio de Janeiro State. All isolates were identified by comparing morphological and cultural characteristics of the fungus with that described in the literature (Boot, 1977; Summerell et al., 2003).

Tomato lines used as race differentials

The cultivars 'Ponderosa' (susceptible to all races), 'IPA-5' (resistant to race 1 due to the presence of the I gene), 'Floradade' (resistant to races 1 and 2 due to the presence of the $I$ and $I-2$ genes) and 'BHRS-2,3' (resistant to all three races probably due to the presence of the $I-3$ gene) were employed as race differential cultivars. Additionally, two accessions belonging to the wild species Solanum pennellii 'CNPH 409' ('LA 716') and S. chilense 'CNPH 410' ('LA 1967'), previously identified as resistant to the tree races (Reis et al., 2004), were also included in the virulence test.

\section{Race characterization assays}

Seeds were sown in styrofoam trays with 128 cells, filled with sterile substrate. When the plants had the first two pairs of true leaves fully open (about 15 days after planting), they were removed from the cells with a gentle jet of water to preserve root integrity. The apical sector of root system (about $2 \mathrm{~cm}$ ) was removed and then dipped for 1 minute in a spore suspension of each isolate adjusted to approximately $2 \times 10^{6}$ conidia/ml, produced in potato dextrose broth under standard conditions (Santos, 1997). As a control, the set of differential accessions was also inoculated with race 1 , race 2 and race 3 isolates. A group of plants from all differential cultivars was mock-inoculated with water. After inoculation, the plantlets were transplanted to $1.5 \mathrm{~kg}$ plastic pots containing sterile soil and maintained in the same greenhouse. The experimental plots were made of three pots with four plants each, in a randomized block design. Disease was assessed 21 days after inoculation using an ordinal scale (1 to 5) where: 1 = plant free of symptoms; 2 = plant without wilt symptoms but presenting conspicuous vascular browning; 3 = plants showing vascular browning symptoms and wilt symptoms but without leaf yellowing; $4=$ severe wilting associated with the presence of foliar necrosis and chlorosis; $5=$ dead plant.

\section{RESULTS AND DISCUSSION}

The seven isolates recovered from wilted tomato plants in Rio de Janeiro State produced colonies, mycelia and conidia with morphological and cultural characteristics typical of the fungus Fusarium oxysporum (Boot, 1977; Summerell et al., 2003). These isolates were virulent on the cultivars 'Ponderosa', 'IPA-5' and 'Floradade'. These results provided strong evidence that they isolates could belong to race 3 . However, the majority of the isolates from Rio de Janeiro were also able to induce wilting symptoms on some plants of the cultivar 'BHRS-2,3' (with the I-3 gene), suggesting that they could represent an additional race. It is interesting to note that an similar response of 'BHRS-2,3' was also observed after inoculation with other race 3 isolates from Espirito Santo State (Reis et al., 2005). The source of race 3 resistance present in 'BHRS-2,3' is derived from S. pennellii 'PI 414773' (McGrath, 1988). However, the phenotypic expression of 'BHRS-2,3' seems to be inferior to that of $S$. pennellii 'LA 716', which is also a source of an allele of the I-3 gene (Hemming et al., 2004), and S. chilense 'LA 1967'. These latter two accessions displayed an immunelike reaction to all seven isolates tested (Table1) and also against race 3 isolates from Espírito Santo (Reis et al., 2004). 


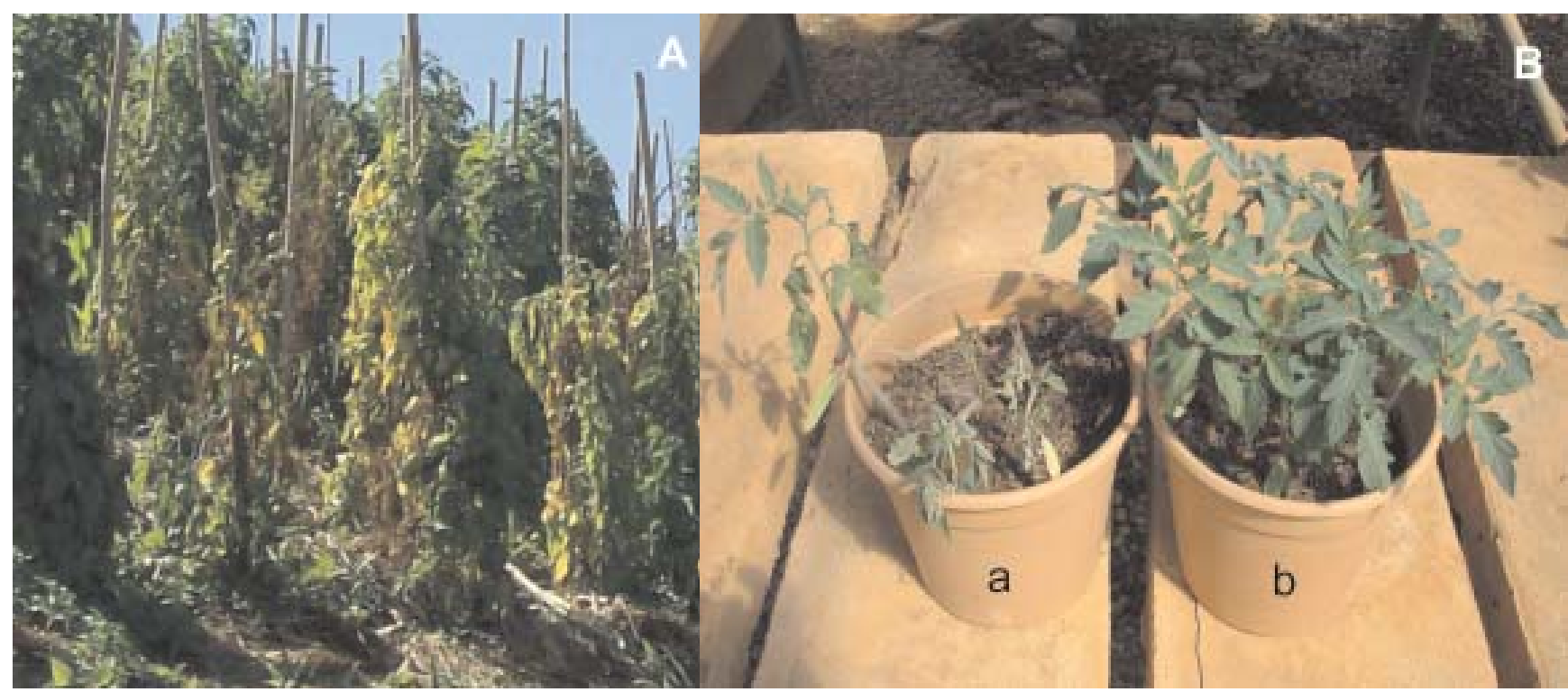

Figure 1. (A) Symptoms of foliar yellowing and vascular wilt caused by Fusarium oxysporum f. sp. lycopersici race 3 in a tomato field in São José de Ubá, (B) Race determination assays under greenhouse conditions showing wilted plants of the cultivar Floradade inoculated with F. oxysporum f. sp. lycopersici race 3 from Rio de Janeiro (a) and control not inoculated (b), (A. Sintomas de amarelecimento foliar e murcha vascular, causado por Fusarium oxysporum f. sp. lycopersici raça 3 em campo de tomate em São José de Ubá, B. Ensaio de determinação de raça, sob condições de casa de vegetação, mostrando plantas murchas da cultivar Floradade inoculadas com F. oxysporum f. sp. lycopersici raça 3 do Estado do Rio de Janeiro (a) e controle não inoculado (b)), Brasília, Embrapa Hortaliças, 2006.

In conclusion, all seven isolates obtained from the hybrids 'Carmen', 'Giovana' and 'Alambra' in tomato fields in Rio de Janeiro State were classified as $F$. oxysporum $\mathrm{f}$. sp. lycopersici race 3 . This race has, so far, a more limited global distribution, being reported in Australia (Grattidge \& O’Brien, 1982); the United States (Chellemi \& Dankers, 1992; Jones, 1991; Jones \& Woltz, 1981; Volin \& Jones, 1982; Cai et al., 2003) and Mexico (Valenzuela-Ureta et al., 1996). In Brazil, F. oxysporum f. sp. lycopersici race 3 was thus far restricted only to Espírito Santo State (Reis et al., 2005). Therefore, the work reported here is the first formal report of race 3 in Rio de Janeiro State, extending the geographical range of this pathogen in Brazil.

Fusarium oxysporum f. sp. lycopersici transmission via contaminated seeds has been reported in the literature (Jones, 1991; Jones \& Woltz, 1981). Contaminated seed is the most likely explanation for the recent introduction of race 3 in Brazil instead of the occurrence of an autochthonous race 3 isolates in these areas, as previously suggested by Reis et al. (2005). The hypothesis of transmission via contaminated seeds is reinforced after the present report, which confirms the almost simultaneous outbreak of race 3 in two geographically isolated tomato-growing areas in Brazil (Espirito Santo and Rio de Janeiro). Evaluation of commercial seed lots imported into Brazil for contamination with the pathogen could be necessary in order to avoid nation-wide spread of this serious disease.

\section{REFERENCES}

ALEXANDER LJ; HOOVER MM. 1955. Disease resistance in wild species of tomato. Ohio Agricultural Experimental Station Research Bulletin 752, 76p.

ALEXANDER LJ; TUCKER CM. 1945. Physiological specialization in the tomato wilt fungus Fusarium oxysporum f. sp. lycopersici. Journal of Agricultural Research 70: 303-313.

ARRUDA SC. 1941. Murcha de Fusarium do tomateiro. Biológico 7: 199-200.

BOHN GW; TUCKER CM. 1940. Studies on Fusarium wilt of the tomato. I. Immunity in Lycopersicon pimpinellifolium Mill. and its inheritance in hybrids. Missouri Agricultural Experimental Station Research Bulletin 311.82p.

BOOTH C. 1977. Fusarium. Laboratory Guide to the Identification of the Major Species. CMI. Kew, England. 58p.

CAI G; ROSEWICH GALE L; SCHNEIDER RW; KISTLER HC; DAVIS RM; ELIAS KS; MIYAO EM. 2003. Origin of race 3 of Fusarium oxysporum f. sp. lycopersici at a single site in California. Phytopathology 93: 1014-1022.
CHELLEMI DO; DANKERS HA. 1992. First report of Fusarium oxysporum f. sp. lycopersici race 3 on tomatoes in Northwest Florida and Georgia. Plant Disease 76: 861.

GRATTIDGE R; O’BRIEN RG. 1982. Occurrence of a third race of Fusarium wilt of tomatoes in Queensland. Plant Disease 66: 165-166.

HEMMING MN; BASUKI S; MCGRATH DJ; CARROLL BJ; JONES DA. 2004. Fine mapping of the tomato $I-3$ gene for fusarium wilt resistance and elimination of a cosegregating resistance gene analogue as a candidate for I-3. Theoretical and Applied Genetics 109: 409-418.

JONES JP. 1991. Fusarium wilt. In: JONES JB; JONES JP; STALL RE; ZITTER TA. (eds.) Compendium of Tomato Diseases. Saint Paul, Minnesota, APS PRESS, p.15.

JONES JP; WOLTZ SS. 1981. Fusarium-incited diseases of tomato and potato and their control. In: NELSON PE; TOUSSOUN TA; COOK RJ. (eds.). Fusarium: Diseases, Biology, and Taxonomy. Pensylvania State University Press, p.157-168.

KUROZAWA C; PAVAN MA. 1997. Doenças do tomateiro. In: KIMATI H; AMORIM L; BERGAMIN FILHO A; CAMARGO LEA; REZENDE JAM. 1997. (eds.). Manual de Fitopatologia. São Paulo, Ceres, p.690-719.

McGRATH DJ. 1988. BHRS 2-3 Fusarium wilt resistant tomato. HortScience 23: 1093-1094.

REIS A; COSTA H; BOITEUX LS; LOPES CA. 2005. First report of Fusarium oxysporum f. sp. lycopersici race 3 on tomato in Brazil. Fitopatologia Brasileira 30: 426-428.

REIS A; GIORDANO LB; LOPES CA; BOITEUX LS. 2004. Novel sources of multiple resistance to three races of Fusarium oxysporum f. sp. lycopersici in Lycopersicon germplasm. Crop Breeding and Applied Biotechnology 4: 495-502. 
SANTOS JRM. 1997. Methodology for Screening Tomato for Fusarium Wilt, Verticillium Wilt, Gray Leaf Spot, Early Blight, and Septoria Leaf Spot. In: Proceedings of the First International Symposium on Tropical Tomato Diseases, ASHS Press, Alexandria, Virginia, USA. p.164-166.

SCOTT JW; JONES JP. 1985 Monogenic resistance in tomato to Fusarium oxysporum f. sp. lycopersici race 3. Euphytica 40: 49-53.
SIMONS G; GROENENDIJK J; WIJBRANDI J; REIJANS M, GROENEN J; DIERGAARDE P; VAN DER LEE T; BLEEKER M; ONSTENK J; DE BOTH M; HARING M; MES J; CORNELISSEN B; ZABEAU M; VOS P. 1998. Dissection of the Fusarium I2 Gene Cluster in Tomato Reveals Six Homologs and One Active Gene Copy. The Plant Cell 10: 1055-1068.
SUMMERELL BA; SALLEH B; LESLIE JF. 2003. A utilitarian approach to Fusarium identification. Plant Disease 87: 117-128.

VALENZUELA-URETA JG; LAWN DA; HEISEY RF; ZAMUDIONALOA V. 1996. First report of Fusarium wilt race 3, caused by Fusarium oxysporum f.sp. lycopersici, of tomato in Mexico. Plant Disease 80: 105.

VOLIN RB; JONES JP. 1982. A new race of Fusarium wilt of tomato in Florida and sources of resistance. Proceedings of Florida State Horticultural Society 95: 268-270. 